\title{
SCIDoC
}

International Journal of Nano Studies \& Technology (IJNST)

ISSN: 2167-8685

\section{Applicability \& Durability Issues Of Nano-Sized Materials In Cement}

Research Article

Mainak Ghosal $^{1 *}$, Arum Kumar Chakraborty ${ }^{2}$

${ }^{1} \mathrm{PhD}$ Research Scholar, Indian Institute of Engineering Science \& Technology, Shibpur, India.

${ }^{2}$ Associate Professor, Dep't of Civil Engineering, Indian Institute of Engineering Science \& Technology, Shibpur, India.

\section{Abstract}

\begin{abstract}
Nano-sized Materials due to their smaller size exhibits many novel properties which may be absent in their conventional bulk material sizes. Cement is the most standard material among all of the materials used in cement concrete constructions and is the only binding medium. This Paper brings out the various beneficial aspects of Nano-sized Materials when they are applied in ordinary cement mortar. Nano-sized Materials viz. Nano Silica (nS), Carbon Nanotubes (CNT) and Nano Titanium Dioxides (n-TiO2) are non-virgin materials but when applied to a virgin cement medium like OPC not only enhances the mechanical properties but also increases the volume stability of cement-mortars to larger extent. Geo-polymers which are very low workability binders having no cement content, has their workability enhancement with Nano-sized Materials.
\end{abstract}

\section{Introduction}

What a 'Nano' is? Is it 'Tata-Nano'? Could anyone tell why it is called 'Nano'? These are the pertinent questions which come in to everyone's mind when they hear about anything called 'Nano'. 'Nano' as it aptly called, is so as it was the world's smallest car invented till now. That was the marketing side of 'Nano' but this Paper discusses the scientific part of it as applied in cement constructions. 'Nano' is a Greek word which means 'dwarf' having dimensions in the order of $10-9 \mathrm{~m}$. Nearly fifty years ago, Richard Feynman who is nicknamed as Albert Einstein-II of this century, is also known as the father of nanotechnology-the technology involving the manufacturing and manipulation of atoms. The construction industry was the only industry to identify nanotechnology as a promising emerging technology in the UK Delphi Survey in the early 1990. ("Application of Nanotechnology in Construction", Materials and Structures, 37, 649 (2004), Springer). But now other industries like tyres, paints, medicines etc have paced ahead lagging construction industry behind. With the on-coming of the 4th industrial revolution as explored by Professor Klaus Schwab, Founder and Executive Chairman, World Economic Forum, also brings up the huge promise of the potentiality of nanotechnol- ogy and Nano-sized Materials. Use of CNTs [4, 5, 20], have produced remarkable improvements in the mechanical properties of cement concrete on account of their crack bridging effects at the nano scale [7] and nucleation effects in the formation of different cement hydrates $[6,17]$ and have replaced the state-ofthe-art technologies using fibers which mainly includes steel bars [18], steel fibers [8, 14, 20], glass fibers [2, 12], carbon fibers [22], polypropylene fibers $[1,10]$, and various others [3]. Literatures [9, $11,13,15,16,21,22]$ are abound highlighting the importance of nano additions in cement concrete.

\section{Materials and Experimental Program}

The materials used were cement-OPC (43 grade), fine aggregate (FA)-river sand conforming to zone II of IS:383-1970, potable water, admixture (super plasticizer)-PolyCarboxylate ether and Nano-sized Materials (viz., nanosilica, carbon nanotubes and nanotitanium oxide). The following Tables (3 to 5) show the specific properties of nanosilica, carbon nanotubes and titanium dioxide used.

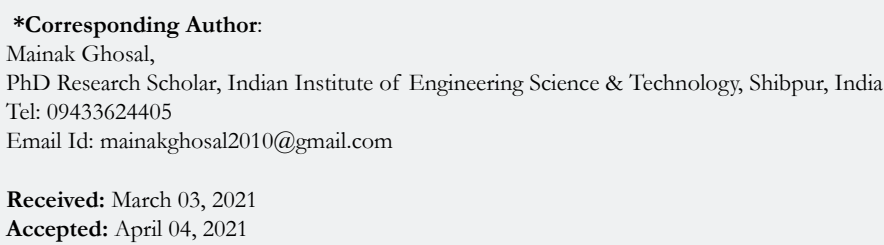

Copyright: Mainak Ghosal ${ }^{\circ} 2021$. This is an open-access article distributed under the terms of the Creative Commons Attribution License, which permits unrestricted use, distribution and reproduction in any medium, provided the original author and source are credited. 
Table 1. Specific Properties \& XRD image of Nanosilica (SiO2).

\begin{tabular}{|c|c|c|c|c|}
\hline Sample/ Brands & $\%$ Content (Lit.) & Specific Gravity(Lab.) & \% Content(Lab.) & Specific Gravity(Lit.) \\
\hline XLP & $14-16 \%$ & 1.12 & $21.4 \%$ & $1.08-1.11$ \\
\hline XTX & $30-32 \%$ & 1.16 & $40.74 \%$ & $1.20-1.22$ \\
\hline XFXLa & $40-43 \%$ & 1.24 & $41.935 \%$ & $1.30-1.32$ \\
\hline & mons & Hous & & \\
\hline
\end{tabular}

Table 2. Specific Properties of Multi-Walled Carbon Nanotubes (Industrial Grade).

\begin{tabular}{|c|c|}
\hline Item & Description \\
\hline DIAMETER & $20-40 \mathrm{~nm}$ \\
\hline LENGTH & $25-45 \mathrm{~nm}$ \\
\hline PURITY & 80-85\% (a/c Raman Spectrometer \& SEM analysis) \\
\hline AMORPHOUS CARBON & $5-8 \%$ \\
\hline RESIDUE (CALCINATION IN AIR) & $5-6 \%$ by $\mathrm{Wt}$. \\
\hline AVERAGE INTERLAYER DISTANCE & $0.34 \mathrm{~nm}$ \\
\hline SPECIFIC SURFACE AREA & $90-220 \mathrm{~m}^{2} / \mathrm{g}$ \\
\hline BULK DENSITY & $0.07-0.32 \mathrm{gm} / \mathrm{cc}$ \\
\hline REAL DENSITY & $1-8 \mathrm{gm} / \mathrm{cc}$ \\
\hline VOLUME RESISTIVITY & $0.1-0.15 \mathrm{ohm} . \mathrm{cm}$ (measured at pressure in powder) \\
\hline 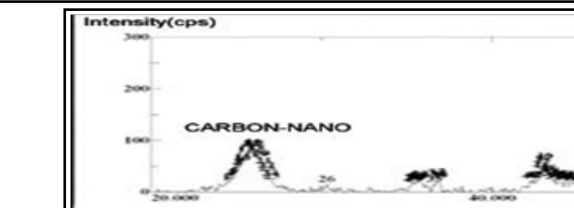 & 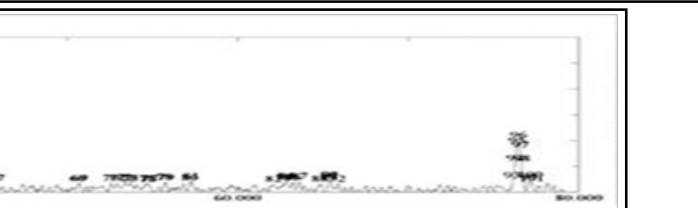 \\
\hline
\end{tabular}

Table 3. Specific Properties of Nanotitanium Oxide (n-TiO2).

\begin{tabular}{|c|c|}
\hline NANO TITANIUM OXIDE $\%$ & 97 \\
\hline RUTILE CONTENT $\%$ & 98 \\
\hline PH & 7 \\
\hline AVERAGE PARTICLE SIZE (TEM) & $30-40 \mathrm{~nm}$ \\
\hline TREATMENT & Nil \\
\hline MOISTURE $\%$ & $1.75-2$ \\
\hline BULK DENSITY & $0.31 \mathrm{gm} / \mathrm{cc}$ \\
\hline WATER SOLUBILITY & In-soluble \\
\hline
\end{tabular}

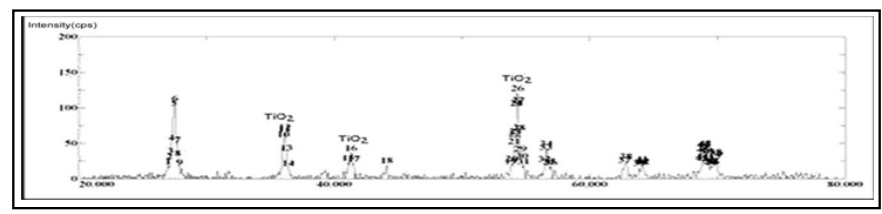

\section{Tests On Hydrated Cement Paste:}

Cement paste containing water added as per normal consistency is taken in a mould $(25 \mathrm{~mm} \times 25 \mathrm{~mm} \times 282 \mathrm{~mm})$ is boiled for a fixed time $(3 \mathrm{hrs})$ at a temperature of $100^{\circ} \mathrm{C}$ under a pressure of 2.1 $\mathrm{N} / \mathrm{mm}^{2}$ in a Autoclave machine and subsequent removing of the specimen \& cooling it in room temperature and measuring the cement paste's dimensions to record any volume change as per IS:4031.

\section{Tests On Cement Composites:}

Mortar Cubes of $70.7 \mathrm{mmx} 70.7 \mathrm{mmx} 70.7 \mathrm{~mm}$ size were casted with 1 part of cement +3 parts of sand with water added as per 
Table 4. Strength (N/ $\left.\mathrm{mm}^{2}\right)$ for Various Proportions/Ages of Nano-added OPC Mortar.

\begin{tabular}{|c|c|c|c|c|c|c|c|c|c|c|c|c|c|c|c|c|}
\hline \multirow[b]{2}{*}{$\begin{array}{l}\text { Sl. } \\
\text { No. }\end{array}$} & \multirow[b]{2}{*}{$\begin{array}{l}\% \text { Nano additions in } \\
\text { Cement (OPC) }\end{array}$} & \multicolumn{3}{|c|}{7 daystrength } & \multicolumn{3}{|c|}{28 daystrength } & \multicolumn{3}{|c|}{90 daystrength } & \multicolumn{3}{|c|}{180 daystrength } & \multicolumn{3}{|c|}{365 daystrength } \\
\hline & & $\begin{array}{l}\text { Individual } \\
\text { Cube } \\
\text { Strength }\end{array}$ & Avg. & $\begin{array}{l}\% \\
\text { in- } \\
\text { crease }\end{array}$ & $\begin{array}{l}\text { Individual } \\
\text { Cube } \\
\text { Strength }\end{array}$ & Avg. & $\begin{array}{l}\% \\
\text { in- } \\
\text { crease }\end{array}$ & $\begin{array}{l}\text { Individ- } \\
\text { ual Cube } \\
\text { Strength }\end{array}$ & Avg. & $\begin{array}{l}\% \\
\text { in- } \\
\text { crease }\end{array}$ & $\begin{array}{l}\text { Indi- } \\
\text { vidual Cube } \\
\text { Strength }\end{array}$ & Avg. & $\begin{array}{l}\% \\
\text { in- } \\
\text { crease }\end{array}$ & $\begin{array}{l}\text { Individual } \\
\text { Cube } \\
\text { Strength }\end{array}$ & Avg. & $\begin{array}{l}\% \\
\text { in- } \\
\text { crease }\end{array}$ \\
\hline \multirow[t]{2}{*}{1} & \multirow{2}{*}{$\begin{array}{c}\mathrm{OPC}(0 \% \mathrm{nS} / \mathrm{CNT} / \\
\left.\mathrm{TiO}_{2}\right)\end{array}$} & 21.08 & \multirow[t]{2}{*}{21.08} & \multirow{2}{*}{$\begin{array}{c}\text { Con- } \\
\text { trol } \\
\text { Sample }\end{array}$} & 28.57 & \multirow[t]{2}{*}{31.89} & \multirow{2}{*}{$\begin{array}{c}\text { Con- } \\
\text { trol } \\
\text { Sam- } \\
\text { ple }\end{array}$} & 38.26 & \multirow[t]{2}{*}{31.20} & \multirow{2}{*}{$\begin{array}{l}\text { Control } \\
\text { Sample }\end{array}$} & 36.22 & \multirow[t]{2}{*}{30.01} & \multirow{2}{*}{$\begin{array}{c}\text { Con- } \\
\text { trol } \\
\text { Sam- } \\
\text { ple }\end{array}$} & 30.01 & \multirow[t]{2}{*}{30.01} & \multirow{2}{*}{$\begin{array}{c}\text { Con- } \\
\text { trol } \\
\text { Sam- } \\
\text { ple }\end{array}$} \\
\hline & & 20.83 & & & 31.89 & & & 31.20 & & & 30.01 & & & 31.01 & & \\
\hline \multirow{3}{*}{2} & \multirow{3}{*}{$\mathrm{OPC}(0.5 \% \mathrm{nS})$} & 21.82 & \multirow{3}{*}{23.85} & \multirow{3}{*}{$13.1 \%$} & 29.68 & & & 41.93 & & & 28.17 & & & 25.76 & & \\
\hline & & 25.87 & & & 41.33 & 35.51 & $11.4 \%$ & 40.67 & 41.3 & $32.7 \%$ & 26.79 & 27.47 & $-9.2 \%$ & 26.76 & 26.76 & $-4.3 \%$ \\
\hline & & 23.85 & & & 35.51 & & & 41.30 & & & 27.47 & & & 27.76 & & \\
\hline & & 28.06 & & & 46.28 & & & 51.75 & & & 40.24 & & & 30.5 & & \\
\hline 3 & OPC $(0.75 \% \mathrm{nS})$ (op- & 27.39 & 2773 & $31.5 \%$ & 38.26 & 42.27 & $32.5 \%$ & 47.95 & 4985 & $598 \%$ & 24.80 & 3252 & $8.4 \%$ & 31.5 & 315 & $4.7 \%$ \\
\hline & & 27.73 & & & 42.27 & & & 49.85 & & & 32.52 & & & 32.5 & & \\
\hline & & 25.15 & & & 31.57 & & & 41.32 & & & 29.59 & & & 31.41 & & \\
\hline & & 25.07 & & & 37.36 & & & 42.98 & & & 33.68 & & & $33 . .41$ & & \\
\hline & & 21.52 & & & 23.47 & & & 33.27 & & & 44.46 & & & 30.3 & & \\
\hline 5 & OPC $(1.25 \% \mathrm{nS})$ & 24.73 & 23.17 & $9.9 \%$ & 38.23 & 30.85 & $3.3 \%$ & 45.63 & 39.45 & $26.4 \%$ & 26.02 & 35.24 & $17.4 \%$ & 31.3 & 31.3 & 4. $3 \%$ \\
\hline & & 23.17 & & & 30.85 & & & 39.45 & & & 35.24 & & & 32.3 & & \\
\hline & & 24.15 & & & 40.89 & & & 34.69 & & & 31.63 & & & 29.12 & & \\
\hline 6 & OPC $(1.5 \% \mathrm{nS})$ & 23.47 & 23.81 & $12.9 \%$ & 34.70 & 37.79 & $18.5 \%$ & 32.14 & 33.42 & $7.1 \%$ & 30.82 & 31.23 & $4.1 \%$ & 29.12 & 29.12 & $-3.0 \%$ \\
\hline & & 23.81 & & & 37.79 & & & 33.42 & & & 31.23 & & & 29.12 & & \\
\hline & & 16.86 & & & 42.35 & & & 34.60 & & & 34.69 & & & 22.83 & & \\
\hline 7 & CNT)(optimized@, & 20.12 & 17.69 & $-10.4 \%$ & 44.63 & 43.75 & $38.7 \%$ & 35.59 & 35.59 & $15.5 \%$ & 33.13 & 30.89 & $10 \%$ & 34.18 & 28.53 & $-4.9 \%$ \\
\hline & & 16.10 & & & 44.27 & & & 36.60 & & & 24.85 & & & 28.57 & & \\
\hline & & 32.56 & & & 41.95 & & & 41.24 & & & 54.30 & & & 34.21 & & \\
\hline 8 & OPC $(0.05 \%$ CNT $)$ & 24.86 & 27.19 & $-16.1 \%$ & 31.35 & 34.88 & $37.2 \%$ & 24.13 & 31.85 & $14.1 \%$ & 31.18 & 38.55 & $3.0 \%$ & 41.69 & 41.69 & $38.9 \%$ \\
\hline 9 & $\mathrm{OPC}(0.1 \% \mathrm{CNT})$ & 20.54 & 21.69 & $28.9 \%$ & 27.00 & 24.83 & $9.4 \%$ & 30.61 & 31.5 & $2.1 \%$ & 32.09 & 30.16 & $23.6 \%$ & 40.24 & 50.78 & $69.2 \%$ \\
\hline & & 20.41 & & & 24.49 & & & 35.71 & & & 30.61 & & & 62.50 & & \\
\hline & & 24.45 & & & 38.70 & & & 33.61 & & & 29.59 & & & 42.47 & & \\
\hline 10 & OPC $(1 \% \mathrm{TiO} 2)$ & 26.02 & 2524 & $197 \%$ & 36.71 & 3671 & $12.6 \%$ & 35.92 & 35.92 & $151 \%$ & 33.42 & 3342 & $11.4 \%$ & 39.86 & 41.16 & $37.2 \%$ \\
\hline & (a) 28 day) & 25.24 & & & 34.72 & & & 38.23 & & & 32.25 & & & 41.16 & & \\
\hline & & 20.05 & & & 36.73 & & & 35.21 & & & $39.24 \%$ & & & 25.51 & & \\
\hline 11 & OPC $(2.5 \% \mathrm{TiO} 2)$ & 20.62 & 20.34 & $-3.5 \%$ & 33.20 & 34.97 & $9.6 \%$ & 37.80 & 37.8 & $21.2 \%$ & 442.66 & 40.95 & $36.5 \%$ & 30.81 & 28.16 & $-6.2 \%$ \\
\hline & & 20.34 & & & 34.97 & & & 40.40 & & & 40.95 & & & 28.16 & & \\
\hline
\end{tabular}

the normal consistency formula of Indian standards.i.e., according to the standard formula $\mathrm{P}^{\prime}=(\mathrm{P} / 4+3)(1$ part Cement +3 parts Sand). Here $\mathrm{P}^{\prime}=$ Quantity of water $\& \mathrm{P}=$ Consistency of Cement used.i.e. amount of water used to make $300 \mathrm{gms}$ cement paste to support a penetration of $5-7 \mathrm{~mm}$ in a standard Vicat mould with a Vicat needle. Nano silica were added in various proportions ranging from $0 \%, 0.5 \%, 0.75 \%, 1.0 \% 1.25 \%, 1.5 \%$, Carbon Nanotubes added in proportions as per literature review i.e., $0.02 \%, 0.05 \%$ $\& 0.1 \%$ and Nano Titanium Oxide added in proportions ranging from $1.0 \% \& 2.5 \%$ w.r.to cement wt. after proper dissolutions in a suitable Super Plastcizer (Poly Carboxylate Ether) (for CNTs \& TiO2 as they were insoluble in water) keeping the w/c ratio fixed at 0.4. The cubes were then ordinary cured under water and tested at 7 days, 28days, 90days, 180 days and 365days as per IS:4031.

For geopolymer concrete, taking alkaline liquid to fly ash ratio by mass $=0.44 \&$ water to geopolymer ratio of $0.25 \&$ assuming that the combined aggregate occupies $79 \%$ of the geopolymer concrete $($ density $=2400 \mathrm{~kg} / \mathrm{m} 3)$ by mass, a design mix was prepared with \& without $\mathrm{nS}$ additions as shown in Fig 2.

\section{The Test Results Shows That:}

The mortar compressive strength as shown in Table $4 \&$ determined as per IS: 4031 shows a $32.55 \%$ increase in strength at $0.75 \% \mathrm{nS}$ addition at 28 days, with the rate of strength gain increasing up to $59.8 \%$ at 90 days but then falling by $8.4 \%$ at 180 days at same optimization. However, for long terms the $1 \% \mathrm{nS}$ addition showed an $8 \%$ increase. For CNTs the gain in strength was $38.7 \%$ at 28 days but falling to $15.48 \%$ at 90 days \& $10 \%$ at 180 days. But $0.1 \%$ CNT shows a strength increase of $69 \%$ at 1 year.

So, for long term for $\mathrm{nS}$ and CNT it is observed that slight increased dosages from the previous optimized @ 28days gave increased strength. Even Geopolymer concrete which is conventionally believed to be viscous in nature had a desired workability (more than 25\% when compared to controlled concrete) when treated with the same optimized dosage of Nano-sized Materials (as per Table 6). 
Figure 1. Effect of nanotechnology \& Nano-sized Materials in construction sector.

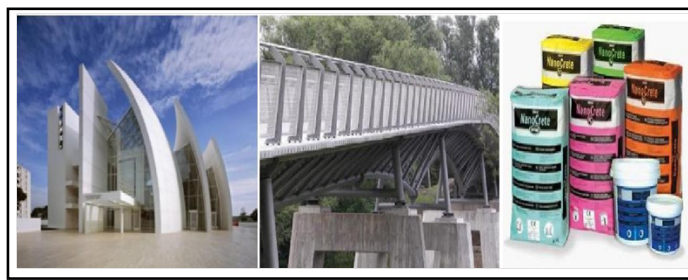

Figure 2. Nano-sized Materials used for Geopolymer concreting and Nanoconcreting in IIESTS Laboratory.

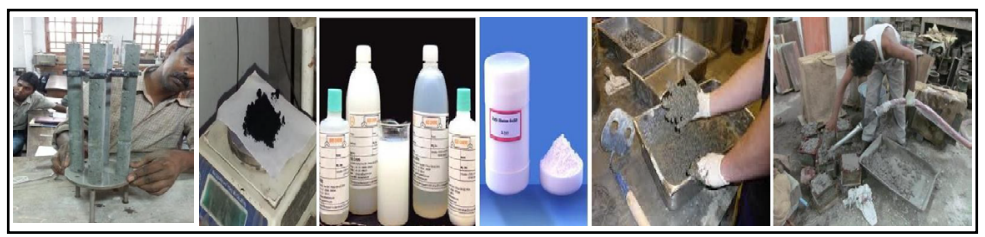

Table 5. Volume Stability of Nano-sized Materials through Autoclaving Tests.

\begin{tabular}{|c|c|c|c|c|}
\hline Type of Cements & $\begin{array}{c}\text { Original Length of } \\
\text { Sample(mm) } \\
\text { [Typical] }\end{array}$ & $\begin{array}{c}\text { Expanded Length of } \\
\text { Sample(mm) after Auto- } \\
\text { claving } \\
\text { [Avg.] }\end{array}$ & $\begin{array}{c}\text { Average Expan- } \\
\text { sion(\%) after } \\
\text { Autoclaving }\end{array}$ & $\begin{array}{c}\text { Resistivity to } \\
\text { Volume Expansion } \\
\text { (in \%) }\end{array}$ \\
\hline 1. OPC & 282 & 282.138 & $0.0490 \%$ & -- \\
\hline $\begin{array}{c}2 . \mathrm{OPC}+0.75 \% \\
\mathrm{~ns}\end{array}$ & 282 & 282.085 & $0.030 \%$ & $38.78 \%$ \\
\hline 3. OPC $+0.02 \% \mathrm{CNT}$ & 282 & 282.021 & $0.0074 \%$ & $84.90 \%$ \\
\hline $\begin{array}{c}\text { 4. OPC }+1.0 \% \\
\mathrm{TiO}\end{array}$ & 282 & 282.042 & $0.0150 \%$ & $69.39 \%$ \\
\hline
\end{tabular}

Table 6. Properties of concrete and geopolymer concrete in presence of Nano-sized Materials.

\begin{tabular}{|c|c|}
\hline Type of Concrete & Fresh Property (Slump) \\
\hline Geopolymer Concrete (nS $=0 \%$ by wt. of Fly Ash) & $100 \mathrm{~mm}$ \\
\hline Geopolymer Concrete (nS $=0.75 \%$ by wt. of Fly Ash) & $130 \mathrm{~mm}(30 \%$ increase) \\
\hline
\end{tabular}

\section{Conclusion}

The results showed that the optimizations for Nano-sized Materials in OPC mortar are $\mathrm{nS}=0.75 \%, \mathrm{CNT}=0.02 \%$ and $\mathrm{TiO} 2=1.0 \%$ for cement mortar up to 28 days. In the long-term strength, some contradictions were noticed for which the reasons are not clear.

It is seen that with the increased addition of nano materials like nano-silica ( $1 \%$ by cement wt.) and carbon nanotubes $(0.1 \%$ by cement wt.) in OPC mortar the long term strength gain increases appreciably.

The optimum percentages based on cement mortar when used in geopolymer concrete produced good results for fresh properties (workability) of geopolymer concrete.

\section{References}

[1]. G.Xu and D.J.Hannant,Cem.Concr.Compos.,1991,Vol 3,pp 95-106.

[2]. S.Marikunte, C.Aldea and S.P.Shah, Adv.Cem. Based Mater.,1997,Vol 5,pp 100-108.

[3]. E.M.Bezerra, A.P.Joaquim Jr, H.Savastano,V.M.John and V.M.Agopyan,
Cem.Concr.Compos., 2006,Vol28,pp 555-563.

[4]. F.Sanchez and C.Ince,Compos.Sci.Technol.,2009,Vol 69, pp 1310-1318.

[5]. Musso S, Tulliani JM, Ferro G, Tagliaferro A. Influence of carbon nanotubes structure on the mechanical behavior of cement composites. Composites Science and Technology. 2009 Sep 1;69(11-12):1985-90.

[6]. M.S.Morsy, S.H.Alsayed and M.Aquel, Construct. Build.Mater., 2011, Vol 25, pp 145-149.

[7]. R.K.Abu Al-Rub, A.I.Ashour and B.M.Tyson, Construct. Build.Mater., 2012,Vol 35, pp 647-655.

[8]. J.P.Won, B.T.Hong, T.J.Choi, S.J.Lee and J.W.Kang, Compos. Struct., 2012,Vol 94, pp 1443-1449.

[9]. Kumar S, Kolay P, Malla S, Mishra S. Effect of multiwalled carbon nanotubes on mechanical strength of cement paste. Journal of Materials in Civil Engineering. 2012 Jan 1;24(1):84-91.

[10]. M.Uysal and H.Tanyildizi, Construct.Build.Mater., 2012,Vol 27,pp 404414.

[11]. Yuvraj S. Experimental research on improvement of concrete strength and enhancing the resisting property of corrosion and permeability by the use of nano silica flyashed concrete. International Journal of Emerging Technology and Advanced Engineering. 2012 Jun;2(6):105-10.

[12]. C.Abeysinghe, D.P.Thambiratnam and N.J.Perera, Compos. Struct.,2013, Vol 95,pp 179-190.

[13]. Abyaneh MR, Mousavi SM, Mehran A, Hoseini SM, Naderi S, Irandoost FM. Effects of nano-silica on permeability of concrete and steel bars reinforcement corrosion. Australian Journal of Basic and Applied Sciences. 2013;7(2):464-7.

[14]. D.Y.Yoo, J.H.Lee and Y.S.Yoon, Compos. Struct., 2013,Vol 106,pp 742753.

[15]. Ghosh A, Sairam V, Bhattacharjee B. Effect of nano-silica on strength and 
microstructure of cement silica fume paste, mortar and concrete. Indian Concrete Journal. 2013 Jun;14(1):11-25.

[16]. Madhavi TC, Pavithra P, Singh SB, Vamsi Raj SB, Paul S. Effect of multiwalled carbon nanotubes on mechanical properties of concrete. International Journal of Scientific Research. 2013 Jun;2(6):166-8.

[17]. Parveen S, Rana S, Fangueiro R. A review on nanomaterial dispersion, microstructure, and mechanical properties of carbon nanotube and nanofiber reinforced cementitious composites. Journal of Nanomaterials. 2013 May;2013.

[18]. E.M.Golafshani, A.Rahai and M.H.Sebt, Construct Build. Mater.,2014,Vol 61,pp 230-240.

[19]. H.K.Kim, I.W.Nam and H.K.Lee, Compos. Struct.,2014,Vol 107,pp 6069.
[20]. S.Tokgoz, C.Dundar and A.K.Tanrikulu, J.Constr.Steel Res., 2014,Vol 74,pp 98-107.

[21]. Ghosal M, Chakraborty AK. A comparative study of nano embedments on different types of cements. International Journal of Advances in Engineering \& Technology. 2015 Apr 1;8(2):92.

[22]. Ghosal M, Chakraborty AK. Behavioral Assesment of Nanoinsertions in Cement Mortar. Recent Trends in Civil Engineering \& Technology. 2015 Oct 6;5(3):15-21. 